\title{
IDENTIFICATION OF WASTE TO BE REGISTERED UNDER THE REACH PROVISIONS IN LATVIA
}

\author{
Kristine Kazerovska ${ }^{a}$ \\ Judite Dipane ${ }^{b}$ \\ Linda Ansone ${ }^{a}$ \\ ${ }^{a}$ University of Latvia, Latvia \\ ${ }^{b}$ Rezekne Higher Education Institution, Latvia
}

\begin{abstract}
Recently, substantial changes have taken place in the European Union (EU) to ensure the safety of chemicals. REACH Regulation (EC) No.1907/2006 has aim to protect the environment and human health from negative impact of chemical substances. New legal requirements set by the REACH will be implemented in all EU Member States according set timeline. Requirement with regard to the registration of chemical substance mainly is targeted towards manufacturers and importers. However, it is relevant also to the companies that are placing on the market recovered waste to be used as raw material by other enterprise later on. It can be noted that some companies are aware of this requirement and they have done already pre-registration of their substances. Nevertheless, overall picture is missing on situation in Latvia. The aim of this research was to assess actual situation on preliminary amounts and types of recovered waste to be registered under $\mathrm{REACH}$ and a number of companies involved. Assessment of available data, e.g. waste management permits, statistical data on waste management of companies as well as interviews with involved stakeholders provided the basis for evaluation of the current situation. The recovered waste material types, shortcomings and scenarios of future developments of REACH implementation in relation to waste area identified and discussed.
\end{abstract}

\section{KEYWORDS}

Waste; Chemical substances; REACH; Chemical supply chain; Latvia.

\section{INTRODUCTION}

Waste material produced by an industrial company could be recovered and ceased to be waste. Recovered substance will be a raw material for the same or another company. It leads also to change in legal obligations to be implemented by an enterprise. Chemicals control is overlapping with many other areas, including waste [1]. Since chemical substances could cause negative impact to the environment either on a local or global scale and have a negative impact on human health either directly or via the environment, the process to ensure the safety of chemical substances is ongoing in the European Union. There are new requirements to be https://doi.org/10.15626/Eco-Tech.2010.053 
implemented set by the Regulation No. 1907/2006 concerning the Registration, Evaluation, Authorization and Restriction of Chemicals (REACH) [2]. Registration of chemical substance is the keystone of REACH and it is mainly targeted towards manufacturers and importers of substances. It is relevant to the companies that are placing on the market their recovered waste material - a substance to be used as raw material later on. Handling of chemical substance shall be according to prescribed safety measures and this information is passed to other actors along the chemicals supply chain as well as obligations on authorisation and restrictions implemented. In order to ensure that chemicals placed on the market are fulfilling new safety obligations, data are necessary for an overview on potential types of recovered waste to be registered. The aim of this research was to assess actual situation on preliminary amounts and types of waste to be registered under REACH and a number of companies involved. Assessment of available data, such as waste management permits, statistical data on waste management of reporting companies as well as interviews with stakeholders provided the basis for evaluation of the current situation. Latvia is used as a case study for the research to identify recovered waste to be potentially registered under the REACH provisions.

\section{CHEMICAL SUPPLY CHAIN}

According to the properties application of chemicals can be very different and involve many processes from their production up to the end of the use of product or article, i.e. whole life cycle of a chemical substance. Therefore, the involvement of a large number of actors in the chemical supply chain is possible. An example of a chemical supply chain and involved actors see in Figure 1. A chemical supply chain can be determined for a single substance and involves all parties using the substance to produce other chemical substances, chemical mixtures or provide a service for client. It can involve actors from different countries, and even from different continents. Manufacturers, importers, downstream users, including formulators and professional users, are actors which increase numerically down the chemical supply chain.

According to REACH, manufacturers and importers at the top of the chemical supply chain, have the highest responsibilities. In comparison to previous European Chemicals legislation, the REACH is intended to increase the speed and efficiency of the risk assessment process of chemical substances and to make manufacturers and importers responsible for the assessment [3]. Therefore, they should ensure availability of information on the properties of the chemical substances. The REACH creates an incentive for manufacturers and importers to take a cautious or even precautious approach to avoid liability problems [4]. Information on risk reduction measures are provided along the chemical supply chain to other actors via Safety Data Sheets [2] and labelling of chemicals. These are most important hazard communication tools to ensure safe use of chemicals. Downstream users receive information on the hazards associated with the chemicals and apply the necessary measures to prevent risk to the environment and human health.

The life cycle and chemical supply chain of a unique substance ends with the waste phase. In case waste is ceases to be waste, then new life cycle of a substance begin. Companies recovering waste shall be aware on their new responsibility to pre-register and register substance produced more than 1 tonne per year, if it has not been registered by another actor. If pre-registration is not done substance cannot legally be placed on the EU market [5]. 
However, not all chemical substances must be registered since exemptions are set. For example, cellulose pulp and recovered glass consisting of certain types of glass are exempted from the registration obligation. An evaluation shall be done by company to reach the conclusion if actions shall be or not implemented before recovered substance is placed on the market.

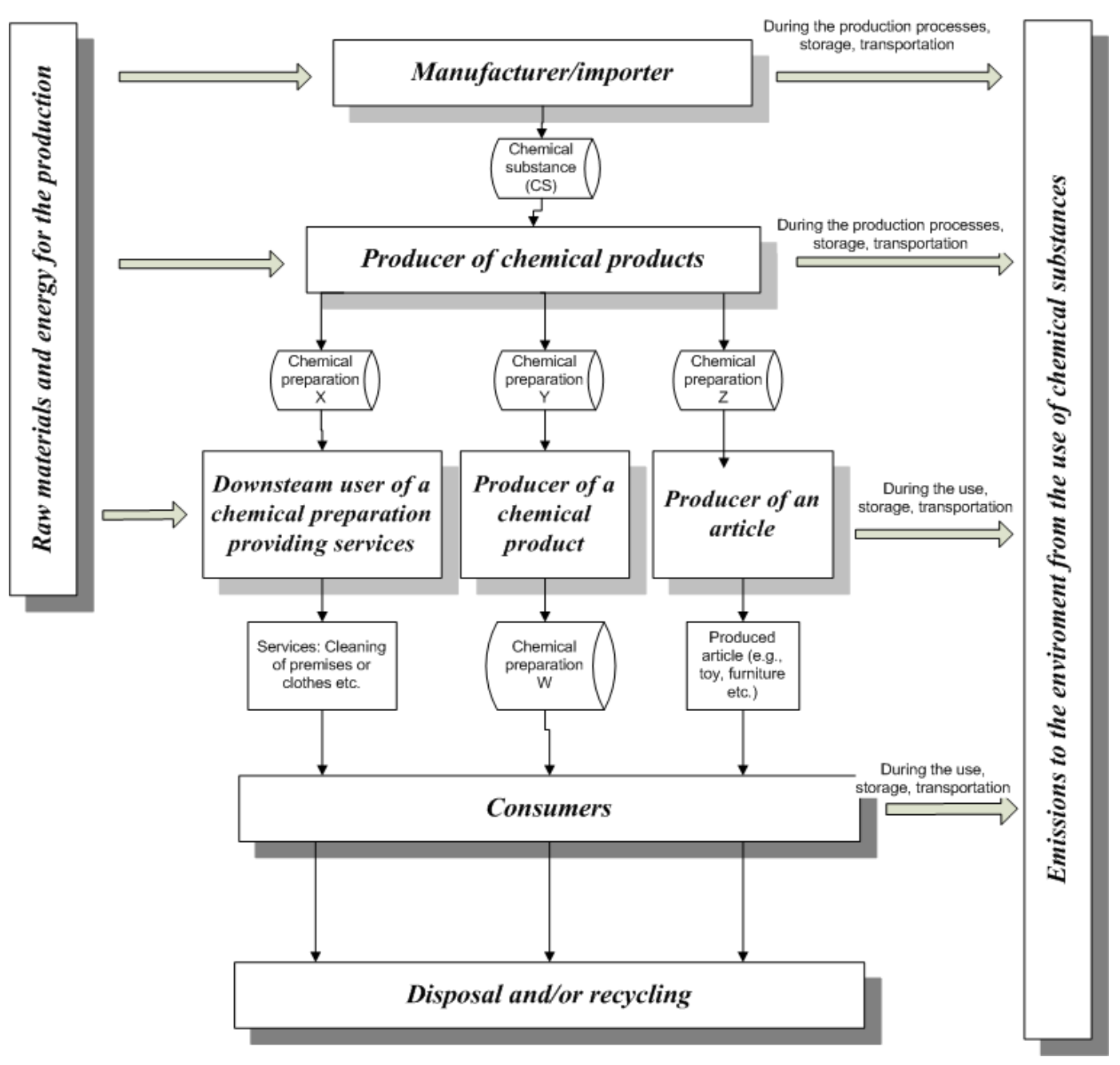

Figure 1. An example of a life cycle of substance and involved actors in the chemical supply chain.

\section{DATA SOURSES ON RECOVERED WASTE MATERIALS}

Since requirement on registration of substances from recovered waste is either new for companies or the enforcement institutions, information is missing on recovered waste and amounts to be potentially registered under REACH provisions in Latvia. Authors have 
identified two data sources to gather information on waste types, amounts and recovery operations relevant for the situation in Latvia and they are described below in Chapter 3.1 and 3.2 .

\subsection{Statistical data on waste production, recovery and import in Latvia}

Industrial companies are obliged to have permits issued by the State Environmental Service for their activities according to the IPPC Directive No. 2008/1/EC. Companies have to collect and provide annual data to Latvian Environment, Geology and Meteorology Centre (LEGMC) on waste, including recovery operations. All data received from the companies are collected in the annual report "No 3 - Report on Waste" providing overview on waste streams in Latvia [6]. Information is available on number of reporting companies in total and companies recovering waste as well as types and amounts of waste materials, including hazardous and non-hazardous, produced, waste materials recovered and waste materials imported into Latvia from other countries.

\subsection{Permits to import waste into Latvia}

Recovery of waste materials or their re-use in industrial processes is also relevant for Latvian enterprises. One of the possibilities to increase amount of waste material for recovery process is to import it from other countries. This action shall be granted by a permit according to Regulation No. 1013/2006 on shipment of waste [7]. Also, this type of permit is issued by the State Environmental Service, which is also Competent Authority for this Regulation in Latvia. Available data on importing activities include name of a company having permit, fixed amount of waste that may be imported and the real amount and type of imported waste material by a company into Latvia.

\subsection{Criteria for data collection}

Authors conducting the research have elaborated the criteria to collect data on recovered waste materials from mentioned data sources in Chapter 3.1. and 3.2., and they are the following:

1. Waste has specific code used for waste classification to identify recovery operation as it occurs in practice [8] (see Table 1).

2. Amount of recovered waste is more than 1 tonne, because according to REACH the threshold for registration of chemical substance is 1 tonne per year;

3. Recovered material of the particular waste stream is not exempted from the registration obligation, e.g. metals, rubber, solvents, oils [5] and it has specific code used for waste type named in Annex V, Part 2 in the Regulation No. 1013/2006 on shipment of waste, e.g. 200140 - Metals [7].

4. Recovering operation has been done in time period from 2007 till 2009 as REACH came into force in 2007 as well as three year period supports to identify the main recovered waste types.

According to classification of waste there are hazardous waste and municipal waste. In scope of this research data were analyse with no distinction. 
Table 1: Classification of waste by codes to identify recovery operation

\begin{tabular}{|c|l|}
\hline $\begin{array}{c}\text { Code for recovery } \\
\text { operations }\end{array}$ & \multicolumn{1}{|c|}{ Description of recovery operation } \\
\hline \hline R 2 & Solvent reclamation/regeneration \\
\hline R 3 & $\begin{array}{l}\text { Recycling/reclamation of organic substances which are not } \\
\text { used as solvents }\end{array}$ \\
\hline R 4 & Recycling/reclamation of metals and metal compounds \\
\hline R 5 & Recycling/reclamation of other inorganic materials \\
\hline R 6 & Regeneration of acids or bases \\
\hline R 7 & Recovery of components used for pollution abatement \\
\hline R 8 & Recovery of components from catalysts \\
\hline
\end{tabular}

\section{RESULTS AND DISCUSSION}

Annual reports on waste provide the general overview on the situation in Latvia [6]. The amount of recovered waste had tendency to increase in time period from 2002 to 2006 (see Figure 1). The amount of recycled waste is $38 \%$ in $2007,48 \%$ in 2008 and $52 \%$ in 2009 in comparison the amount of total waste. In the EU $46 \%$ of waste were recovered in 2008 [9].

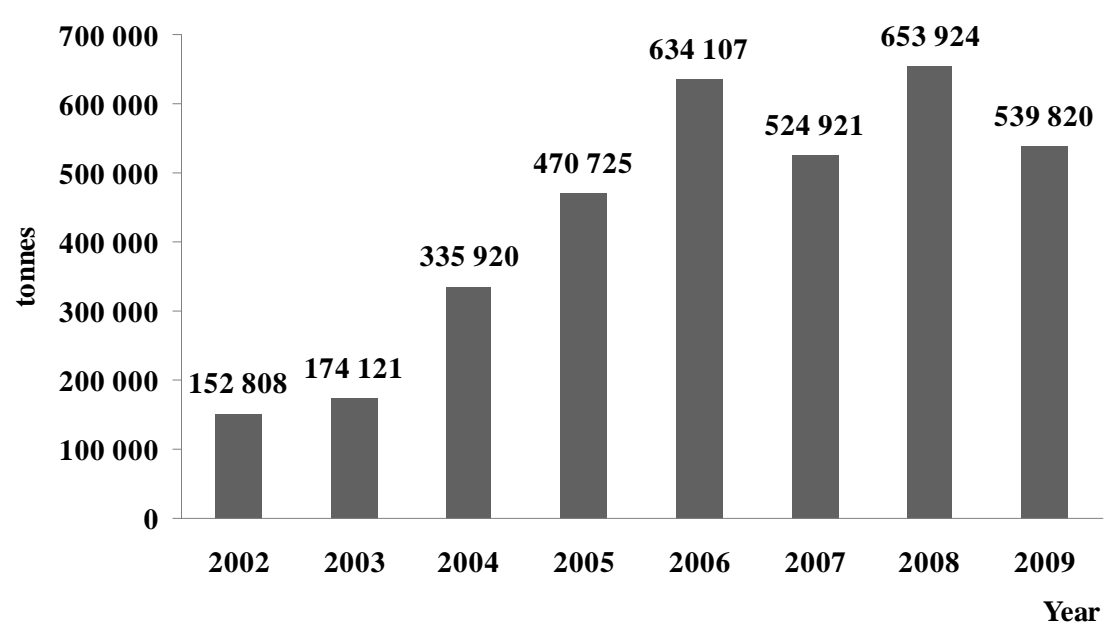

Figure 1. Annual amounts of the recovered waste in time period from 2002 -2009 [6].

In total 5-6\% (i.e. 168-200 companies) companies are reporting on their recovering processes. Collection of the data from a single company's report having recycling operation would be complicated process demanding high resources. Therefore, at first screening of recovered waste types was performed in Latvia. There are four main types of recovered waste materials in time period of three years (see Table 2). The highest amounts in tonnes of recycles waste material are for metals and it has increasing tendency. According to the data from Central 
Statistical Bureau of Latvia manufacturing of basic metals and metal products and is one of the main industry branches by production volume in time period from 2006-2008 [10].

Table 2 Recovered waste materials above 1 tonne a year in time period from 2007-2009 [6].

\begin{tabular}{|c|c|l|c|c|c|}
\hline \hline $\begin{array}{c}\text { Code for } \\
\text { recovery } \\
\text { operations }\end{array}$ & $\begin{array}{c}\text { Code for } \\
\text { waste } \\
\text { type }\end{array}$ & \multicolumn{1}{|c|}{ Description } & 2007 & 2008 & 2009 \\
\cline { 3 - 6 } & 150102 & Plastic packaging & 8052 & 4650,4 & 4302,10 \\
\hline \hline R3 & 191204 & Plastic and rubber & 285 & 305 & 484 \\
\hline R3 & 200140 & Metals & 10062,739 & 14541,618 & 116896,1 \\
\hline R4 & 200121 & $\begin{array}{l}\text { Fluorescent tubes and other } \\
\text { mercury-containing waste }\end{array}$ & 290,199 & 388,6 & 228,212 \\
\hline
\end{tabular}

Such recovered waste materials classified as Paint, inks, adhesives and resins containing dangerous substances (R2, 200127) is 1,31 t in 2007, Solid salts and solutions containing heavy metals (R5, 060313) - 18,15 t in 2009, Skimmings other than those mentioned in 1003 15 ( $\mathrm{R} 4,1003$ 16) is recovered $185,179 \mathrm{t}$ in 2007 and $470.377 \mathrm{t}$ in 2009 . On the one hand, no tendency has identified for the recovering process in the selected time period. On the other hand, REACH set obligation for a substance manufactured or imported more than 1 tonne a year.

Also, data on import of waste in Latvia shows the high numbers in tonnage for metals (code 200140) (see Table 3). 
Table 3 Types and amounts of waste materials imported in time period from 2007 - 2009 [6].

\begin{tabular}{|c|l|c|c|c|}
\hline \multirow{2}{*}{$\begin{array}{c}\text { Code for } \\
\text { waste type }\end{array}$} & \multicolumn{1}{|c|}{ Description } & 2007 & 2008 & 2009 \\
\cline { 3 - 5 } & & \multicolumn{2}{|c|}{ Recovered amount, t } \\
\hline \hline 200121 & $\begin{array}{l}\text { Fluorescent tubes and other mercury- } \\
\text { containing waste }\end{array}$ & 147,39 & 191,047 & 129,962 \\
\hline 070213 & Waste plastic & No data & No data & 3977,453 \\
\hline 160602 & Ni-Cd batteries & No data & No data & 22,18 \\
\hline 150102 & Plastic packaging & 3472,513 & 21 & 1868,33 \\
\hline 191204 & Plastic and rubber & 150 & 180 & 360 \\
\hline 200139 & Plastics & No data & 3235 & 534,629 \\
\hline 200140 & Metals & 2840,5 & 9191,862 & 5294,017 \\
\hline
\end{tabular}

List of the permits issued for the companies to import waste into Latvia provides possibility to identify at least a part of companies and their imported amounts of the waste by recovery operation codes and waste type codes. In total 5 companies have imported waste, including some waste types named in Table 2, in 2009. This information assists to find out company identification and imported amounts and target enforcement actions by environmental inspectors.

It was commented by representative from LEGMC that data could not be complete since not all companies are reporting annually. It is essential for the data assessment that codes are selected correctly for each waste type. Also, discrepancies in the terminology was identified that term "Import" in annual reports was relevant for waste brought from both the EU and non-EU countries. It was clarified that LEGMC as Competent Authority for REACH have provided consultancy on pre-registration of substances for the companies that are recovering metals as well as plastic processing. It shows the awareness of some companies on their new responsibilities.

It is clarified that data on amounts of recovered chemical substances are not reported to the environmental institutions and no requirements are existing on such reporting. Since waste material could have a various mixture of many chemical substances, there is necessity to clarify exact recovered substance name, purity and recovered amount. A solution would be direct communication to a company, for example, during enforcement activities to indentify annual amount of a specific substance recycled. Such data would be available only for enforcement authorities as they have legal power to ask information on production volumes that is very sensitive for companies due to competition. 


\section{CONCLUSIONS}

The enterprises recovering waste materials could meet new obligations coming from REACH regulation that is aiming at higher level of protection of the environment and human health. There are recovered chemical substances that should be pre-registered and registered later on. Up today there is missing overview on existing situation on recovered waste material in relation to REACH requirements in Latvia.

The research conducted on recovered waste materials above 1 tonne a year in time period from 2007 - 2009 identifies main waste types such as metals; plastic packaging; plastic and rubber; fluorescent tubes and other mercury-containing waste. Companies recovering those materials shall be informed on obligations and determine if they have obligation on registration. There are also other recovered waste materials that are above 1 tonne a year, and have to fulfil registration obligation, too. It is also possible to identify companies importing waste for recovery processes if they are applying for the permits to import.

Available data on waste management do not provide names and real amounts of recovered substances per year for a single company. The only solution is to have direct contact to the company with the intention to collect data on production amounts. This research could provide an approach how to identify the target companies and specific types of waste influenced by REACH regulation.

\section{ACKNOWLEDGMENTS}

The authors would like to thank the State Environmental Service of the Republic of Latvia for providing data and the European Social Fund for financially supporting this study.

\section{REFERENCES}

[1] Assmuth, T., Hildén, M., Craye, M., 2010. Beyond REACH: Roadblocks and shortcuts en route to integrated risk assessment and management of chemicals. Science of The Total Environment, 408 (18), 3954-3963.

[2] EC Regulation (EC) No 1907/2006 of the European Parliament and of the Council of 18 December 2006 concerning the Registration, Evaluation, Authorisation and Restriction of Chemicals (REACH), establishing a European Chemicals Agency, amending Directive 1999/45/EC and repealing Council Regulation (EEC) No 793/93 and Commission Regulation (EC) No 1488/94 as well as Council Directive 76/769/EEC and Commission Directives 91/155/EEC, 93/67/EEC, 93/105/EC and 2000/21/EC, Official Journal of the European Union, 396, 1-849. Available: http://eurlex.europa.eu/LexUriServ/LexUriServ.do?uri=CELEX:32006R1907:EN:NOT (accessed October 13, 2010).

[3] Ruden C., Hansson, S.O., 2006. Improving REACH. Regulatory toxicology and pharmacology, 44 (1), 33-42.

[4] Warhurst, A.M., 2006. Assessing and managing the hazards and risks of chemicals in the real world - the role of the EU's REACH proposal in future regulation of chemicals. Environment International, 32, 1033-1042. 
[5] European Chemicals Agency, 2010. Guidance on waste and recovered substances. 36p. Available: http://guidance.echa.europa.eu/guidance_en.htm (accessed on October 13 2010).

[6] Latvian Environment, Geology and Meteorology Centre, 2010. State Statistical Reports "No 3 - Report on Waste". Available: http://www.meteo.lv/public/ 28759.html?highlite $=$ YXRrcml0dW1p (accessed on October 13, 2010).

[7] EC Regulation No 1013/2006 of the European Parliament and of the Council of 14 June 2006 on shipments of waste. Available: http://eur-lex.europa.eu/LexUriServ/ LexUriServ.do?uri=CELEX:32006R1013:EN:NOT (accessed on October 13, 2010).

[8] EC Directive 2006/12/EC of the European Parliament and of the Council of 5 April 2006 on waste. Available: http://eur-lex.europa.eu/LexUriServ/ LexUriServ.do?uri=CELEX:32006L0012:EN:NOT (accessed on October 13, 2010).

[9] EUROSTAT, Waste statistics. Available: http://epp.eurostat.ec.europa.eu/ statistics_explained/index.php/Waste_statistics (accessed on October 13, 2010).

[10] Central Statistical Bureau of the Republic of Latvia, 2010. Data base on Industry. Available: http://data.csb.gov.lv/DATABASEEN/rupnbuvn/Annual\%20statistical \%20data/16.\%20Industry/16.\%20Industry.asp (accessed on October 13, 2010). 